Performance, art et anthropologie

\title{
Ritual, Performance and Bodily Transformation
}

\section{Kjersti Larsen}

\section{(2) OpenEdition}

\section{Journals}

Electronic version

URL: http://journals.openedition.org/actesbranly/449

DOI: 10.4000/actesbranly.449

ISSN: 2105-2735

\section{Publisher}

Musée du quai Branly Jacques Chirac

Electronic reference

Kjersti Larsen, «Ritual, Performance and Bodily Transformation», Les actes de colloques du musée du quai Branly Jacques Chirac [Online], 2 | 2009, Online since 21 December 2009, connection on 21 December 2020. URL : http://journals.openedition.org/actesbranly/449 ; DOI : https://doi.org/ 10.4000/actesbranly.449

This text was automatically generated on 21 December 2020.

(c) Tous droits réservés 


\title{
Ritual, Performance and Bodily Transformation
}

\author{
Kjersti Larsen
}

1 The paper explores bodily transformations in the context of the phenomenon of spirit possession in Zanzibar on the coast of East Africa ${ }^{1}$. It explores how performance theory and performative genres may provide concepts applicable in our understandings of possession phenomena where people involved perceive spirits as part of human reality and, furthermore, the spirits, not humans, are ascribed capacity to embody human beings at will. Ethnographically the focus is on the spirits called masheitani or majinni and rituals performed on their behalf, ngoma ya sheitani. Central to my discussion is that trough relations with spirits people in this particular society become, I argue, disassociated from but also, I hold, re-associated with their identity. The spirits are known to have the capacity to embody human beings and through this process materialize in the human world. Important to keep in mind when discussing this possession phenomenon is exactly that a process of embodiment implies a distinction between the one embodied and the one embodying; between humans and spirits.

Ngoma ya sheitani constitute a particular occasion organized on behalf of spirits. In this sense it is by Zanzibaris defined as events set apart from those of everydaylife yet still part of daily social life. To Zanzibaris the exisitence of spirits (majinni, masheitani) is not in itself questioned and the idea of being temporarily inhabited by spirits is not perceived as anything abnormal, not even unusual. Saying this I wish to emphasize that for Zanzibaris ngoma ya sheitani cannot, as for performance theorists more generally, be seen as an analogy to theatre. A question following from this is still whether a theatre analogy can still be helpful in understanding ritual and forms of interaction and transformation taking place in the ritual context or whether such an approach could rather be misleading given that it ignores problems of authenticity and focus enactment. As Kelly Askew rightly points out: 'If everything is enactment, then what is reality'? (Askew 2002: 21). In terms of social anthropological theory I refer to ngoma ya sheitani as a ritual not as performance but will still draw on performance theory in order to analyze how and why embodying spirits become included in Zanzibari reality 
and why they should be approached as such by, for instance, researchers. My argument rests, obviously, on the understanding that there are variations in how reality and meaning is conceptualized between different societies as well as, to a lesser degree, within societies.

Referring to ngoma ya sheitani as ritual I underline the fact that these events are part of social life and that how and why they are performed and organize can only be fully grasped if seen in relation to broader cosmological understandings including the reality of spirits and their effects on people's life and thus their relationships (see also Turner 1977, 1984, 1988). The participants in these rituals are women, men of different age and spirits whose engagement is mainly motivated by a wish to improve and secure prosperity and contentment in their lives. As such they are not taking part as artist in the aim of re-presenting reality or in order to understand life in terms of itself. In this sense, as performance ngoma ya sheitani should be seen as an event and a process actively engaged in by everyone in attendance and not as a pre-composed product 'owned' by performers and transmitted for audience reception (see also Askew 2002: 40).

In my approach to ritual I emphasize that what takes place within ritual should not be understood as being outside time. It is perhaps a slowing down of the tempo characterizing daily life; less chaotic, more ordered and controllable where certain aspects of lived reality are scrutinized and others not. In this sense, rituals are special forms of social actions which go beyond ordinary form of communication and, with respect to ngoma ya sheitani, include an explicit focus on aesthetics and body language. What takes place inside and outside rituals are equally part of reality - it is equally real. It is in the connectedness of the two dimensions of reality that the dynamics of life worlds could be identified. If a distinction should be brought in it could be, as Bruce Kapferer insists in his more recent work (2004), that between actuality and virtuality where the ritual space produced provides a dynamic that, in Kapferers words, 'allows for all kinds of potentialities of human experience to take shape and form' (Ibid :47). Following from this perspective, it is the chaotic dimension of ordinary lived processes that constitutes the reality of actuality, not the virtual reality of ritual.

Performance theorists often argue that what ritual does is communicate, and it is through this function that ritual indirectly affects social relations and perception of realities. It is, however, more appropriate to say that ritual or, also, ritualized enactment include communication. Rituals do not only express aspects of reality; through performance reality is negotiated. Rituals are not mere reflectors or representations of social life and people's concerns rather, rituals provide a basis for dialogue as well as reflection, and therefore make possible negotiations about a common understanding of social reality. Performance and per formative acts are part of the ritual context and important in the sense that performance implies an active construction of social life and active communication and interaction between and among performers including audience. Currently, the concept, mimesis in the sense of an active representation based on a knowing subject is applied in the study of possession phenomena (Benjamin 1955; Taussig 1993) and what Judith Butler (1988) calls "performative acts". Approaching ngoma ya sheitani as a ritual and cultural performance means that, in my view, such events should be studied exactly because these are contexts through which different dimensions of peoples' lived reality and experience available, both to the anthropologist and to people themselves - although in 
different ways. Moreover, acts taking place in ritual space may either conform to or contest the expectations which are grounded in perceptions of, in the case of characteristics of humans and spirits, the physical body understood as temporarily transformable and as seat of different persona.

6 Zanzibar situated off the Coast of East Africa consists of the two islands Unguja and Pemba and is a semi-autonomous polity in the united republic of Tanzania. The population amounts to approximately one million people. Zanzibar Town being the capital of Zanzibar is a small island community with dense inter-communality and crosscutting kinship and affinal ties. Although the vast majority of the population shares a Muslim faith, Zanzibar can best be described as a multicultural society and people themselves refer to different places of origin beyond Zanzibar in order to identify themselves and others. They consider that they are all Zanzibaris but associated with different makabila (singl. kabila), a term Zanzibaris themselves would translate into the English tribes or populations. Difference in origin is in daily life mainly associated with variations of preferences regarding particular forms of aesthetics, food and movements - and, is usually talked about as habits (tabia) or also conventions (desturi) but can in confliction and politically defined context take on more violent forms (Larsen 2004). Moreover, minor differences in language-use and religious and ritual practices are used as cultural markers (Larsen 1998, 2008). Applying the term multicultural I refer to a society that over time has developed a shared form of social organization, value system and ideals which includes an understanding of difference from within.

7 Social distinctions apply in this society to, as already mentioned, an idea of makabila but also to gender, social rank and social-cultural positioning. Historically there has in Zanzibar been a tendency to evaluate everything associated with being Muslim and from Arabia as representing aesthetic as well as life-style related ideals. However, such ideals are in light of the cosmopolitan character and current political upheavals ambiguous and constantly contested. Identities and social relationships are in this multicultural and sex-segregated society complex. There is a concern about know how to manage in public life between what kind of behaviour, relationships and lifesituation to disclose in front of others and what should be concealed. Appearance is critical as well as awareness about what is and what ought to be. This means that there are in this society shared ideas and values and simultaneously, a recognition of life as being multifaceted and not always lived according to the shared ideals. As Mohamed Saleh (2009) writes about the experienced dilemmas many Zanzibaris face between the 'is and ought to be' - it concerns, he argues, the problem of 'dini wal dunia', the world and religion.

8 Islam is central in the lives of most Zanzibaris and women and men strive to be what they consider 'good Muslims' and thus, to live according to the teachings of Islam and Zanzibari morality - which is, most of the time, considered to be the same thing. The spirits are, generally speaking, included in a Zanzibari, Islamic reality. The spirits called majinni or masheitani (singl. jinni or sheitani), are said to be created (umbwa) and sent to earth (dunia ardhini) by God. On earth live human beings, animals and spirits, although spirits also have a spirit-world of their own and angels are found in heaven. While spirits are said to interact with living human beings, the angels are thought to take care of humans after they have died and before they meet $\mathrm{God}^{2}$. Spirit form part of Islamic cosmology and are described in one chapter of the Qur'an (Sura LXXII Jinn) ${ }^{3}$. These 
spirit beings, known as jinn in the Qur'an, are recognized in orthodox Islamic doctrine. They are, however, mentioned in such contradictory ways that Muslim scholars have never been able to agree on their natures and powers (Gray 1969). Still to make a distinction between core and peripheral elements of Islam when discussing the spirits and the phenomenon of spirit possession in Zanzibar Town would be misleading. Seeing the spirit phenomenon as peripheral to Islam implies that certain discourses are accepted as more valid than others ${ }^{4}$. To individual Zanzibari women and men, the spirits and the various practices related to spirits are more or less central and peripheral in their life depending on their situation and the presence or absence of happiness, contentment or illness. Spirits materialize during rituals performed on their behalf but also in the course of everyday-life. Moreover, the spirits presence in everyday reality is continuously re-created through ongoing discourses about them, their characteristics and doings.

In the human world spirits are disembodied, although they are said to have bodies in the spirit world - bodies similar to those of dwarfs. In order to materialise in the human world, spirits are said to inhabit and use the body of human beings. In these situations the human body is conceptualised as a spirit's temporal seat (kiti). Thus, the body is the locus of spirit possession and the spirits' utterances include in addition to music, songs and words also postures, gestures, preferences in fragrances and taste, and movements. As individuals the spirits are persons in that they have specific social identities distinct from the people they inhabit. The social identities of the spirits are emphasised through the spirits' personal and family names, places of origin as well as by their known life histories. It is important to notice that difference of makabila, that is, 'tribes' relates both to humans and spirits alike. This means that the spirits called majinni or masheitani are said to come from places beyond Zanzibar itself.

Throughout the presentation I shall maintain that when Zanzibari women and men embody spirits, they become the spirits. Important to keep in mind is that Zanzibaris would not project human situations onto the spirits. Spirits are not understood to only exist in the world to solve human dilemmas. It just happens that they do so from time to time. Spirits and humans are seen as different beings despite the fact that both are sharing a body in the human world. To this extent the spirits form part of a process where self is at the same time coupled and separated from non-self (see also Boddy 1989). The distinction between a human self and a spirit self, or between self and nonself, also makes possible a continuous contextualization through which who one is or is not can be negotiated; a process which may remind us that a sense of self is actually tied to the ambiguity of self and other (Evens 1994). Below I will illustrate how the kinds of spirits a person embody are linked to aspects of her or his identity. The case of Bi Khatija shows how people through the spirits may be both disassociated and reassociated with dimensions of their identity; with who they are or are not and in their relations with others.

11 Bi Khatija, a woman in her sixties, has four spirits who are all belonging to what is conceptualized as different kabila. She has one Arab, Muslim spirit (sheitani ya ruhani) who is the kind of spirit perceived as most in concordance with images of being Zanzibari and good Muslim. She also has a pagan, Swahili spirit from Pemba (sheitani ya rubamba), a kind of spirit less in concordance with images of at least urban, educated Zanzibariness. Bi Khatija also has a Christian spirit from Ethiopia, sheitani ya kihabeshia. This kind of spirit reflects, as I have discussed elsewhere and in line with Linda Giles 
(1987), relationship between an Arab dynasty and a slave population. Finally, she has a Christian spirit from Madagascar (sheitani ya kibuki) and who are known to be attracted first and foremost to Zanzibaris of Comorian origin. Bi Khatija is a Zanzibari who has lived most of her life in Zanzibar Town, in a neighbourhood bordering Stone Town. She is a good Muslim, celebrating urban ideals and values and, yet, as many others, she is associated with a low social rank. Bi Khatija, herself, never stresses her origin. Still other people claim that she is Mswahili, a term usually applied in order to indicate slave origin. Bi Khatija herself if asked would say that her great grandmother arrived in Zanzibar as a slave. Furthermore, many of Bi Khatija's neighbours and close friends are of Comorian origin (wangasija). Bi Khatija's only daughter married a man of Comorian origin and as such her granddaughter who is living with her, is partly Comorian and has, as Bi Khatija, a sheitani ya kibuki. The various spirits are one after the other present and they introduce themselves as is expected of them, by referring to their first name, father and grandfather's name and most importantly, places of origin. Appearing they are not perceived to represent anyone or anything beyond who they are and what they do in their dialogue and interaction with everybody present. Yet, seen from a distance it appears that the spirits who possess Bi Khatija are all associated with life-styles and socio-cultural positions that in different ways are constitutive of her own life history or, rather, that these spirits are important to Bi Khatija because of experiences and lived reality. To my knowledge, it is not coincidental that the kinds of spirits embodying people, in one way or another, echoes aspects of their life history, or, also, embrace various facets of their rather complex yet flexible Zanzibari identity. Possessing spirits may retain specific memories and guide social behaviour. They may influence how a person sees her- or himself and relates to the surroundings. The case of Bi Khatija illustrates how being inhabited by spirits of a gender and 'tribe' different from the person whose body the spirit uses in the process may become both disassociated from and re-associated with different dimensions of their identity. While the spirits materialize through human bodies, the relationships produced between humans and their embodying spirits make possible not only reflections on identity, morality and the other but also negotiation of ones one identity in relation to other. Still, questions relating to consciousness and reality and, following from this, the significance of human imaginary in the constitution of reality may be raised.

During rituals performed on behalf of spirits the physical presence of spirits is clearly marked. Moreover, ngoma ya sheitani constitutes processes through which space, objects and bodies are transformed. The bodily transformations taking place presupposes, however, a particular understanding of the body, relations between body and mind as well as existing forms of presences.

During ritual various objects and practices are engaged in marking the identity of the particular kind of spirit celebrated on a given occasion as well as distinctions between persons and the spirits. To arrange ngoma ya sheitani, people must first know the kabila or 'tribe' of the spirit in question. Only when it has become clear which tribe the spirit in question belongs to, will people know what sort of incense to burn, greetings to use, sort of ingredients and remedies to use, the mixture of herbs and special objects, food and drinks claimed by the different spirits, which colours thespirits prefer on their own as well as participants clothes, the kind of music or rhythm, scents they prefer and which language thespirit speaks. ${ }^{5}$ The different kinds of spirits known to Zanzibaris are, as already mentioned, distinct with regard to aesthetics including bodily movements and gesture (for further elaboration see Larsen 1998, 2008). The likes and dislikes of, for 
instance, masheitani ya kibuki (Christian spirits from Madagascar) and masheitani ya ruhani (Muslim spirits from Arabia) are quite different and, moreover, the ways and habits of masheitani ya kibuki divert from what is usually considered acceptable by the Zanzibari society while the ways and habits of masheitani ya ruhani are much in concordance what is usually considered acceptable by the Zanzibari society (Larsen 1998). Seen in the light of Zanzibari dominant moral ideals masheitani ya kibuki are excessive or transgressive and, for instance, their preference for drinking alcohol is explained by the fact that these spirits are Christians, not Muslims as are most Zanzibaris. Below I shall describe parts of a ritual performed on behalf of Christian spirits from Madagascar - ngoma ya kibuki - as an illustration for discussing processes of spacial and bodily transformation.

Ngoma ya kibuki, as other forms of ngoma ya sheitani, lasts, in most cases, from five and seven days and are usually performed in and around the house of a ritual leader (fundi) $)^{5}$.The participants consist of the ritual leader, the one performing the ritual on behalf of her or his spirit, mwele, members for the ritual group in question (kilinge), relatives and friends of mwele, people who themselves embody spirits of the given tribe and people of the neighbourhood. This means that the audience consists of women and men of different age, that is, children, youth, adults and elderly. The members of the ritual group can go in and out of the house as they like while friends have to be invited $i^{6}$. Otherwise the audience - some invited while others have heard about the event and decided to attend - stays outside the house. More peripheral voyeurs will in the late evening and night, watch from a distance.

For ngoma ya kibuki a tarpaulin is arranged as a tent with three walls, just outside the main entrance door of the house in order to give protection against the sun and what is considered unnecessary voyeurism. On the ground straw mats are arranged in order to make a floor. Among the significant artefacts in connection with masheitani ya kibuki are two big wooden chairs and in one end of the room - the end directed towards the spirits' place of origin, Madagascar there is a table decorated with the herbs these spirits use in order to prepare their special healing water. Other crucial and observable artefacts are the main remedies of the spirits placed on the table; a bucket filled with the spirits specially prepared water, the incense jars, the white plates with Maria Theresa coins, other coins, silver bracelets, the spirits' special water mixed with limestone, talmalandi, some honey, bottles of imported brandy, cups and glasses and tobacco and betel-nut. The summoning of the spirits, their self-presentation, their clothes and the colours used, the celebrating and the dancing that takes place in this tent like construction where also the audience is seated, are necessary elements which arrangement transforms the courtyard into space accommodation, in this particular case, spirits from Madagascar.

16 The ritual starts when the members of the ritual group come out of the house carrying the spirits precious ebony spears or sceptres with sophisticated silver ornamentation, incense jars and white plates with silver coins and bracelets. The music and rhythm is made from rattles (kayamba), accordion, electric piano andclapping and thesongs are in the kibuki-language ${ }^{7 \cdot}$ Recently CDs or cassettes with Malagasy music and songs are used during the main parts of the rituals. The fragrance of the incense special to this tribe of spirits, a mixture of udi and sandarusi, is clearly sensed. While proceeding, the women, together with those who had already arrived in order to form the audience, are singing the opening song praising the great ones among the kings of this tribe of spirits ${ }^{8}$. The 
spirits of some of the members of the ritual group will already at this point have arrived. Some would have been embodying their spirits from the moment they sensed the incense and heard their special music and songs, while women who have prepared the special kibuki remedy will on and off, have been embodying their spirits since the morning. Exact knowledge about the ingredients of this remedy, is held by members of the ritual group only.

When the procession is over, all present, people and spirits alike, will sit down on the floor and the ritual leader will say a prayer to masheitani ya kibuki in the language of kibuki: "You know our problems; help us in the work we have to do, and if we may arrange for her/him help her/him so that she/he can give out her/his name"'. While saying the prayer, all present hold their hands in the way familiar to contexts where people ensure their trust and faith in God and repeat kwesto, which, I was told, has the same meaning as amin in Swahili (amen).The ritual leader Bi Amani is said to know the kibuki language - their language from Madagascar, ki-buki. No one, not even the ritual leader, will give an exact translation into Swahili of, for instance, the opening song referred to above. Still, they all agree that the general meaning of the song is as follows: 'you, the kings, you know everything' (Habari zote nyinyi, wafalme mnazijua) ${ }^{10}$. When the prayer have come to an end, all people present are censed - one after the other, and talmalandi (limestone mixed with water) will be smeared on people's foreheads, necks, breast and temples. Thereafter, they are given the spirits' special herbal infusion to drink from a white plate before again being censed. This is seen as a remedy to protect humans from illness and suffering.

When suddenly the ritual leader Bi Amani's start to shiver, her legs jumping, two women who belong in the ritual group will rush to assist her as this is the sign that the spirits are about to enter her body through the feet. Her legs will be rubbed with brandy in order to facilitate the process and make the spirit feel comfortable while Bi Amani will be making sounds as if she were about to throw up. When a spirit has eventually arrived in her head Bi Amani's head is sprinkled with the special water, and only then calmness is regained. She had got her spirit - the king ( $\mathrm{mfalme}$ ) in her head $(\text { kichwani })^{11}$. The king is called Babu, which means grandfather, although his real name is Ndamandizirivo. His wife is Mzinzarivo. The names sound exotic to someone familiar with Swahili names. As a king, Babu always wants his feet on a stool (kibao), and the sceptre in his hand. As a sign of respect all of the spirits and persons present greeted Babu in the prescribed way: they kneel in front of him and, then, Babu puts his hand on their head. All who want to be present during the ritual should, when they arrive greet the fundi Bi Amani by kneeling in front of her and Babu when he has arrived. Then they should move on to greet other great ones (wakubwa) among masheitani ya kibuki ${ }^{12}$. It should be noted that masheitani ya kibuki in contrast to other kinds of spirits known to Zanzibaris, always appear in couples. This means that Bi Amani referred to above would, for instance, be embodying both the king and queen of masheitani ya kibuki, but never in the same moment. As one spirit leaves her body, the other may embody her. This further implies that in the ritual context of masheitani ya kibuki, participants constantly observe and experience the human body shifting between being female and male.

In the centre of the room, both masheitani ya kibuki and members of the ritual group who at this point in the ritual do not have their spirits in their heads will be dancing with bodily movements particular to spirits of this tribe (wabuki). Many of the members 
of the ritual group wear silver jewellery special to this tribe of spirits, and the sceptres decorated with Indian silver work. Male and female spirits move differently, are dressed differently, and have different facial expressions; male spirits have an air of authority, while female spirits have smiles on their faces and douse people in the audience with perfume. Male spirits hold spears in their hands, while females have covered their heads and sometimes the lower part of their faces with a shawl. In the ritual context the differences between women and men, female and male, are accentuated precisely because the spirits appear in couples, and that the same human body continuously changes between being inhabited by female and male spirits. When it becomes clear whether it is the female or male spirit who arrives, humans or spirits present ensure that the human body is dressed correctly according to the gender the spirit ${ }^{13}$.

Humans and spirits remain distinct beings. People interact with spirits and during rituals interaction with the audience is usually initiated by the spirits. If the spirits are attracted to someone among the audience they will give them coins, and they also ask coins from the audience ${ }^{14}$. Spirits have according to their place of origin a language different from Zanzibaris. Difference in language is one among several markers of difference. Whenever the spirits are happy they will utter what is said to be a kibuki term for expressing respect and contentment, that is, kwayz and people in the audience are expected to reply with kwayz whenever the spirits offer or show them something. The spirits bring people in the audience to the king so they can receive his blessings; also the king may call on certain people in the audience when he recognises that they have a spirit. The spirits ask money from people in the audience and sometimes the spirits also give out money to people whom the like ${ }^{15}$. Money is called barata in kibuki language while in Swahili the terms pesa or feddah are used. The spirits also give away brandy called barissa in the kibuki language ${ }^{16}$, to those whom they like. If they are in a good mood they might even give brandy to those in the audience who ask for brandy. Some bring small bottles so that they can pour the brandy offered them by the spirits into these in order to use the brandy as 'medicine' (dawa) whenever that should be required. When someone in the audience asks the spirits to give them brandy to drink, other people present will whisper that they attend the ritual only because they like being drunk. Simultaneously, people in the audience who are offered brandy have to drink it. If they reject the drink offered to them, the spirit will usually empty the cup on the head of that person. Both the drinking of brandy and the act of emptying a cup on the head of a person are perceived as disruptive acts, although these are anticipated and part of the programmed performance. Masheitani ya kibuki are the only spirits who demand alcohol ${ }^{17}$. To drink alcohol and, moreover, to drink alcohol in public is perceived as a moral transgression for women and men alike.

21 People in the audience have not yet arranged for their spirits, and therefore they are not part of the ritual group. Still, they are continuously inhabited by the spirits and in the process their bodies are transformed. Their spirits usually scream as they arrive and can neither stand up on their feet, nor introduce themselves with their full names. As people's spirits climb to their heads they will start to move the upper part of their bodies in a circle with their eyes wide open and gazing with intensity, as if, on something or someone far away. Eventually they will get up on their knees and make their way to the centre of the room, where they will dance on their knees until the spirits decide to leave again. 

female spirit who then went towards a young woman with long straight hair. The spirit started to play with the young woman's hair while making it clear to all present that she found this hair beautiful. She even tried to put the hair onto Zainab's head. When she did not succeed she became angry and started to undo Zainab's hair quite violently, while telling the audience through bodily movements and gestures how horrible she found Zainab's hair, that is, the hair belonging to the woman whose body the spirit had inhabited, and how much she liked the hair of the young girl. The spirit, as well as the audience, distinguished between Zainab and herself as different beings. The audience looked at the spirit laughingly and made jokes about her preferring the hair of someone else. 'She is foolish,' they said, 'she should be pleased with Zainab's hair. Zainab cannot change her hair.' By expressing a dislike for Zainab's hair by favouring the hair of the other woman, the spirit is also making a value judgment: that Zainab's hair is not the sort of hair considered beautiful according the ideal standards. In this society, people not spirits are easily shamed if they express feelings of, for instance, jealousy in front of others, as such behaviour reveals their own misery and discontent. Spirits can openly express emotions like jealousy, desire and greed without being shamed.

When I later on discussed the situation described above with Zainab she said that she felt embarrassed and humiliated because of how her spirit had focused on her hair. 'I do not like to be laughed at; it is shameful,' she told me. Zainab explained that she had been aware of what her spirit did but was not able to control the spirit. When the spirit had left, she had also been told about her spirit's behaviour by people present. In this situation, it seems that although it was the spirit's conduct that evoked laughter, Zainab felt embarrassed as if she were the one who had misbehaved. Does this mean that the boundaries between Zainab and her spirit are, in one way or another, blurred? Is it that Zainab feels shame because she has, through the spirit, revealed in front of other people that she longs for the sort of hair she does not have - the kind of hair associated with Arab origin or rather Arabness? One possibility for Zainab's feeling of shame is that the spirit made fun of her when she was not present to defend herself: it is like being gossiped about publicly or, also, like being insulted in front of other people and thereby losing face (vunja uso). After all, it was her spirit's judgment of her hair that they were laughing at.

It seems that the behaviour of Zainab's spirit carried over into everyday life. Zainab was worried that her spirit's behaviour would have an impact on how she was viewed by others. The relationship between a human being and a spirit may lead to revelations about the human host that cause embarrassment on the part of the human host. In this sense, the phenomenon of embodying a spirit and thereby losing control over one's body may appear threatening. Likewise, a relationship between a human being and a spirit may spill over on to the human host and cause embarrassment if the human host could, by relating to the spirit in a different way, have prevented the embarrassing or shameful situation.

Humans and spirits are, in the context of Zanzibar, perceived as different kinds of beings. In general, the difference between humans and spirits should be seen as one of excess rather than reversal. As such, parody - not in terms of satire but rather as repetition with critical distance - plays an important part in bodily transformations especially in the context of the rituals called ngoma ya sheitani. In the process of 
transformation participants are, I hold, engaged in an interactional creation of what can be called a 'performance reality'. This implies that meanings are generated in social space through performance and that performance should be seen a fundamental dimension of any culture and important in the production of knowledge about culture. Through performance people both enact and extend their knowledge about who they are or are not, about various others and about society. Important regarding knowledge representation is, I argue, that rituals may give the participants a possibility of experiencing reality in the sense that people reflect on other contexts of meaning in the performance setting and in the social and cultural world out of which the ritual emerges. I am aware that participants in a performance do not necessarily share a common experience or even agree on its meaning. However, what they do share is the experience of participation. Still, ritualization both implies and demonstrates a relatively unified corporate body, often leading participants to assume that there is more consensus than there actually is (Bell 1992). This relative lack of consensus results from the fact that those involved in rituals are differently positioned within society, and as individuals they bring in their experiences.

Acting, dancing and moving represent symbolic transformations of human experience, but if the code of the body language is not apprehended, the empirically perceived messages will be misunderstood. In ritual contexts the behaviour of spirits is evaluated on the basis of their emotional expressions such as bodily movements, facial expressions and dance.Moreover, the meanings assigned to aesthetic representations are not intrinsic, but depend on the meanings that are assigned or associated with various bodily movements and facial expressions in different sociocultural contexts (Hanna 1988). Body language, as we conceive of it, is not a function of the individual mover or dancer; it is a shared language about experience - that is, experience not only as thought but also as sensation and perception (see Merleau-Ponty 1962). Moreover, within ritual and in performance, emotions and discourses on emotions are part of the language through which transformations are marked. As knowledgeable and reflective actors, people engage creatively with the world and, as Catherine Lutz and Geoffrey White argue, emotion concepts are likely to be actively used in the negotiation of social reality. The semantic uses of the body and of the space in which it moves are important dimensions in studies of emotions, which also have bearing on my analysis of the sprit phenomenon and ngoma ya sheitani.

The behaviour of spirits is concomitantly characterized by its similarity to human behaviour and by its transgressions of significant distinctions, such as that between concealment and disclosure. Although, it might be through their relationships with spirits that women and men come to terms with what I see as discontinuities between their ideals and values and their lived experiences, the ritual or performative process also conveys the limitations of ritual and ritual experiences in transformative terms. What is communicated can transgress the experiences of individual women and men, but it cannot, I hold, move beyond that which is imaginable to the people present.

The difference between humans and spirits is, as mentioned above, one of excess rather than reversal. As such, parody seems to play an important part in ngoma ya sheitani. Linda Hutcheon defines parody not in terms of satire but rather as repetition with critical distance (Hutcheon 1985: 6), where difference is marked through similarities or resemblance. She claims that parody is always intended and that the intention is to parody certain conventions. Thus in order to parody one has to recognize this intention 
and possess the capacity to identify the reference that will make the parody understood as such (ibid.). In the case of the Zanzibari spirit phenomenon, I am reluctant to ascribe clear intentions to either the spirits' actions or people's relations with spirits. At the same time, I hold that both the spirits' doings and sayings, and the interactions between human beings and spirits, may appear to people present as a parody of human life. The spirits present and represent both cultural stereotypes and individual idiosyncrasies. In ritual contexts where spirits and humans meet, there is, due to elements of improvisation and play, ample room for both. Observing the behaviour and manners of spirits seems to make possible a displacement of subjective experience and a linking of this experience to others through the mediation of shared constructions and typifications as Bruce Kapferer (1983) also argues for Sri Lanka.

Moreover, important in rituals is the dimension of play, which makes possible communication about how reality could have been different. Concerning differentiation between humans and spirits it should, for instance, be noted that one distinction is, precisely, tied to the practice of sexsegregation. In the ritual ngoma ya kibuki, the spirits' ignorance of sex-segregation is easily noticed precisely because the spirits express sexual attraction towards each other as well as towards people present during the ritual (for further elaboration see Larsen 2008).In the human world, the practice of sexsegregation prevents intimate relations between women and men from being disclosed publicly.

An important difference between humans and spirits is that in the human world spirits are without their own bodies. In order to materialize in the human world, spirits inhabit the bodies of human beings of both the same and the opposite sex. The body, whether one focuses on physical or aesthetic differences, becomes central with regard to questions of gender and with respect to differences between human beings and spirits, as they share a body in the human world. The body also becomes a focus for the articulation of difference with respect to notions of kabila as well as gender. All these ideas of differences are in particular revealed in the condensed contexts of the ritual ngoma ya sheitani, where human beings and gendered spirits belonging to various makabila meet. Through embodying gendered spirits belonging to various makabila, the human body becomes transformed. This transformation of the human body is, I suggest, grounded in aesthetics, performance as well as emotional and sensual percepts. To be inhabited by a spirit can be described as a performative and physical form of othering. The body becomes not only a focus for difference and sameness but also a locus for the articulation of difference and sameness. Human bodies become the seat of the other, and as human bodies perform, the other may appear. Inspired by Judith Butler's argument on performative aspect of identity (Butler 1988, 1993, 2006), I would say that rather than seeing acts and gestures as expressive of spirits, the reality of spirits is performative (1988: 527).

31 Foucault $(1977,1985)$ reminds us about the primacy of practice over belief. Our bodies are trained, shaped, and impressed with the stamp of prevailing historical forms of selfhood, desire, masculinity and femininity: not chiefly through ideology, but through the organization and regulation of the time, space and movements of our daily lives. In the process of being inhabited by spirits, people can observe the distinction between self and other and experience otherness in relation to gender, origin and worldview. Through mimesis understood as a creative process, people may actually become transformed into the other. Involved in this movement - both in the sense of being 
moved and in understanding the process of transformation - are, precisely, aspects of aesthetics, body language, emotional concepts and the senses.

Physical senses and sensual experiences are essential in the process of transformation whereby humans become inhabited by spirits. In order to call spirits and to make them happy, Zanzibaris appeal to the spirits' sensory experiences: sight, through colours, jewellery and flowers; flavour, by serving and consuming food and drink; sound, through flattering words and use of special formulas and terms as well as certain sorts of instruments, music and songs; and smell, through the use of incense and flowers, rosewater, perfume and aromatic oils. Smell, sight, taste and sound involve aesthetics, and aesthetics carry the potential for crossing barriers and invoking transformations. Concentrating on sensory experiences, processes of transformation that are essential to a ritual context can, according to Paul Stoller, be made visible and social memory evoked $(1989,1995)$. People's interactions and engagement with the spirits focus the attention of all. It is a process through which feelings and imaginations are shaped into certain forms. The following scene will illustrate such a process.

Once, at a ritual, one of the participants suddenly disappeared. When she returned I asked her where she had been. She explained that she had had to run away in order to prevent her spirit from climbing to her head. She said:

Spirits are attracted by fragrance, sound, taste and colours. If during a ritual you feel that the spirit is about to enter your body, you can run away so that you neither smell the scents of incense or perfumes nor hear the songs or the music. Then the spirit may leave again. But that does not always work. Quite often the spirit will still climb to your head and oblige you to return, because so eager the spirit is to participate in the ritual.

Spirits are attracted by and called for through sensual means. The senses play an important part in experiences of altered states of body and altered states of mind. The aesthetic merging of human beings and spirits, performers and audience, that takes place in the ritual contexts create and recreate the reality of spirits. In these contexts judgments, sentiments and the body become appropriated in responding to human beings inhabited by spirits. This process presupposes, however, an understanding of the body as permeable and as a potential seat of various distinct selves. When a spirits leave a human body, the persons whose bodies they have used are exhausted and in pain. When embodying a sheitani ya kibuki a person will sometimes be left with bleeding knees and partly destroyed clothes. In this situation, people will receive medicine for their knees, given by smearing brandy and limestone on their wounds, which is quite painful. The wounds and the pain humans feel in the wake of embodying spirits, is as I have discussed elsewhere (Larsen 2008) often used to argue the reality of spirits. This means that the physical body is marked by the spirits' presence and the felt pain become, perhaps, the spirit or, at least, a sign of acknowledging the presence of someone else in you. Underpinning the reality of spirits materializing in the human world is a perceived distinction between a person and her or his spirit. On the basis of this distinction, the spirits become part of reality detached from and independent of human beings. Yet, while remaining as disembodied beings in the human world, the spirits are attached to and conditioned by human bodies. Thus, the existence of spirits is once more clearly linked to the idea of difference as incorporated both in society and within the human body.

36 I maintain that when women and men embody spirits they become the spirits. In Zanzibar Town people make a distinction between spirits and themselves - a 
distinction which can, then, be linked to an idea of difference on another level, that is, the distinction between self and other. Thus, we are here witnessing a continuous process of differentiation and identification. Embodying spirits of a gender and tribe different from that of the person whose body the spirit uses may produce a process through which a person whose body is inhabited may become disassociated from her or his identity yet it may also, as in the case of Bi Khatija described above, produce a form of re-association with certain dimensions of their identity. The process through which people become inhabited by spirits can be described in terms of mimesis (Kramer 1993) or the capacity to other (Taussig1993: 129). Mimesis is understood as the capacity to redirect our attention to the body and also to the body subject (Merleau-Ponty 1962) - a perspective challenging a certain understanding of knowledge and knowledge formation where culture is mainly seen as constructed through a theoretically based discourse (Taussig 1993). Through mimesis - which is explicitly tied to the body people can dramatize and negotiate understandings of themselves, of relationships or of their own society in relation to ideas of the other and other societies. Accordingly, through the phenomenon of masheitani difference is incorporated into the Zanzibari society. By being inhabited by gendered spirits belonging to different makabila with different traditions, habits and religions, women and men come to see not only the other, but also themselves. Inherent, then, in the phenomenon of masheitani is selfinterpretation via the other like in the case of Bi Khatija discussed above. Mimesis denotes conformity with something else or an other - that one conforms to someone or something that one is not and also should not be. A generally recognized difference between the portrayer and the portrayed is an absolute prerequisite for mimetic behaviour - this point is critical in order to understand relations between humans and haunting beings in Zanzibar.

By becoming the spirit, the character of the performer is cast as that which she or he represents. This process is in line with what Kramer (1993: 200) labels 'aesthetic empathy'. It refers to a process where non-human agencies are understood to enter a person in order to make them-selves visible and able to act in the world. The term aesthetic empathy echoes a Zanzibari perception of relationships between people and spirits. Zanzibari women and men hold that spirits inhabit human bodies at will, in order to materialize in the human world and get what they want from human beings. What Zanzibaris observe when humans embody spirits, are the voice, eyes and movements of the other within familiar bodies, and not a host empathizing with a memorized script and handed-down phenomenon (Kramer 1993). Zainab referred to above, becomes her spirits; she is not acting like a spirit - she is the spirit. Her voice changes, as do the words she speaks; the expression in her eyes changes, as well as how her gaze is perceived; her body movements and gestures change, as does her conduct. When the spirit leaves her body, she feels physical pain due to the way her spirit has used her body. Her body is marked by the pain and through the pain the spirit remains present.

Spirits materialize in the human world as different beings from the person whose body they inhabit as illustrated above in the case of Zainab and her spirit. During certain sequences in a process of embodiment boundaries appear as being blurred. This is not due to a lack of differentiation between human beings and spirits. Rather it is caused by the fact that what spirits do may spill over onto the involved person and the involved person onto the spirit. While spirits may cause feelings of shame and suffering on the part of their human hosts, the human hosts, in their turn, may cause disappointment 
and anger to the spirits as in the situation where Zainab's spirit ridicules her hair and, perhaps, the message that she is not, although this is how she appears, of high social rank and Arabic origin.

The phenomenon of masheitani is also based on knowledge about the other. In order to relate to the spirits people have to interpret various kinds of gestures and bodily movements, as well as engage in and interpret objects and rules of aesthetics. This is precisely what the phenomenon of masheitani is about with its encompassing dynamics. People must come to know the language of the other. Understood in this way, the term mimesis denotes a creative process and refers to a form of situated knowledge where the act of replication also includes an interpretation of those who are replicated. It is through this form of knowledge that people communicates about who they themselves are or are not and, as I have shown, come to recognize themselves in the spirits.

The reason why people accept what they see and feel in relation to the spirits as reality is not so much a question of what Zanzibaris believe is happening as it is of how what they believe is brought to life in a continually re-created ritual space or performance event (see also Schieffelin 1993). Through the course of performance and whenever spirits enter this world, ritual space is recreated. In this situation, the ritual leader, the members of the ritual group and the spirits present must commit the audience to the task of participating in the construction of the ritual space. This is again accomplished through mimesis, but also through the singing done by both humans and spirits, and through interaction between human beings and spirits. As the people present engage with the spirits, the spirits become live personalities and, thus, the reality of the spirit world is created in the interaction between people and spirits.

41 I have emphasized relations between humans and spirits in performance events in order to suggest one way of analysing a phenomenon were people may both become disassociated from and reassociated with dimensions of their identity. Performance events as ritual provide a basis for dialogue and reflection, and therefore make possible negotiations about a common understanding of social reality including identity, positioning and relationships. Embodying foreign spirits implies, among other things, that experiences other than those that are ideologically and politically immediately accessible can be reflected upon and reproduced by means of enactment, through gesture and aesthetics. Through the process of enacting a foreign spirit, more or less unknown experiences become known and familiar and, hence, incorporated by the individual. By being played out in public, this knowledge takes on a social dimension and is also incorporated by the larger collective. In this sense, being inhabited by foreign spirits concerns practical activity - it is production, rather than mere representation. Humans and spirits do not merely imitate each other. They in fact become each other, as far as Zanzibaris are concerned. Through becoming an other, that is, a spirit, individual persons inhabited by spirits along with those observing the process of transformation, enter new fields of understanding. Taking the position of the other, human beings come to experience the emotions and dilemmas of other members of society and to act upon them by themselves being transformed into another social identity. In doing so, they come to see the world from various perspectives. Hence, the possession phenomenon as understood and practiced by women and men in Zanzibar Town presents less certain forms of knowledge than they express actual modes of knowing. 
In their specific approach, participant observation, anthropologists do stress the creative dimension of mimesis. By participating in everyday-life and thus using their own bodies in similar ways as others in the same environment (Jackson 1989), they are supposed to position themselves in the place of the other, and thereby, gain the possibility of experiencing the world as an other. Their methodological concern and, thus, their understanding of how to acquire knowledge, actually, acknowledges the importance of embodied knowledge, lived experience, and intersubjectivity, and does not only emphasize mind and rationalism in the Cartesian sense. This is important to bear in mind, because understanding or knowledge does not only consist of after-thefact reflections on prior experiences; but is rather formed by the way they, in the process, acquire experiences (Johnson 1987: 104). Subsequent philosophical reflections on our experiences are made possible simply by the more basic modes of understandings (ibid). As fieldworkers, however, anthropologists can only hope to occupy one position within a society while there are, obviously, many positions. The current emphasis on culture as a domain of competing and conflicting meanings that are continuously contested draws our attention to the necessity of investigating multiple subject positions as well as multiple models of reality. Such a definition of culture has also inspired a greater awareness of the importance of contextual interpretation, and problems related to the body and mind construct are no exception.

\section{Discussion}

Public: You mentioned quite early in your paper that these dances result from the embodiment of the person by a spirit. They are not merely a function, but the mean of medication between the world of spirits will or the spirit itself and the person that is being inhabited. Do you also think that there takes place a communication between the spirit and the inhabited person who, as you said, becomes the spirit and the person who observes the entire thing?

Kjersti Larsen: What you usually find is that there is no communication between the person whose body the spirit uses and the spirit. Because the idea or the "Zanzibarian understanding", would be that when the spirit embodies the human body the human mind is put aside. Because from their perspective there is no blurring between the spirit mind and the human mind. So there may be communication between the spirit and other people present.

Caterina Pasqualino : Je pense peut-être que c'est le moment d'en profiter pour revenir au coeur du débat. Jusqu'à maintenant on a parlé du rapport entre le rituel et la performance, et on a parlé des choses que le rituel et la performance ont en commun. Là on peut peut-être signaler quels sont les éléments qui les séparent. Puisque ce colloque s'intitule "performance, art et anthropologie » l'accent est évidemment le rituel mais finalement on ne parle que de ça. Ce que l'on peut dire est que du côté du rituel on attend plus de résultats, il y a un lien avec le transcendant, on est du côté d'un éternel présent, l'acteur est plus du côté du procédé et l'audience participe plus, et on n'y croit plus. Alors que du côté de la performance, on peut quand même dire que c'est plus du côté de l'amusement. Il s'agit d'un moment présent délimité (il se termine quand même), qui est plus du côté historique, où l'acteur a conscience de ce qu'il fait (même si parfois il perd cette conscience), l'audience qui participe aussi est peut-être 
plus du côté de l'écoute. Il y a quand même des questions très générales à poser sur non seulement en ce qui réunit le rituel et la performance, mais aussi sur ce qui les sépare.

Richard Schechner:Do people specialize, do people get possessed by the same spirit over and over again, and thereby get recognized in the community as specialists in being possessed by this particular spirit?

Kjersti Larsen: Of course. There are not only specialists who will get possessed by spirits. It is not like Shamanism. Everybody can be possessed by a spirit. The point is that when you have performed the ritual, when you have acknowledged the spirit, in order to welcome the spirit and to establish a relationship with the spirit then the same spirit will reappear. Many persons of course then have several spirits. All of these are known and the people in the surrounding also know them by name, place of origin and so on. The same spirits will then reappear. You can have a spirit for life time.

Richard Schechner: The audience or the participants learn to expect that this particular person can be possessed by this particular spirit and I assume that there is a kind of similarity of gestures and sounds issued from performance to performance. Is that true?

Kjersti Larsen: What I tried to say very briefly in the beginning is that each category of spirit (what they would call "tribes" of spirits) are known by their special colours, fragrances, kind of music, food habits and this is quite stereotypical in this society. It is the society where the idea is that all people and spirits come from places outside Zanzibar. They are all Zanzibaris but they all have an origin outside, this goes for the people as well as for the spirits. So, the people merge and share and idea of zanzinariness, a common culture, a value system.

Richard Schechner: Let's imagine that I am an anthropologist from Mars, I have just arrived. So, how do I tell the difference between this what you describe and regular theatre? Because I see some very good theatre in which the people perform and become the character, while we are there we know their character and get familiar, especially with movie stars who perform the same kind of role over and over again, the same gestures. So, I am from Mars. I don't know. Which is which? How would you tell me: is there a ritual and this is theatre? Is there something intrinsic in the performance itself that makes it different?

51 Kjersti Larsen: Probably we wouldn't ever discover if we are not engaged with the people of the society. They give you the various clues and hints and how to read the various scenes in front of you.

Craigie Horsfield:Kjersti you spoke throughout and this has been central to your presentation the relation between spirits and people. In the familiar model of anthropology (contemporary anthropology) you gave the spirits an existence, that being, which you are distant from and implicated in. I don't know from your presentation, and indeed I should not, whether you believe in this spirits as existing beyond the people or whether throughout you conceived them as a formal social structure. I should note that Richard Schechner spoke of his spirit earlier on. I want to understand a little bit where does this distinction between belief, actuality and social structure lay. How do you find your way through this, what are you doing here?

Kjersti Larsen:Of course is a very important question and you can say that researching on this phenomenon I made the choice that I would like to approach the spirit to understand the Zanzibarian approach to the spirit. There is no point for me in 
understanding the spirit for itself, in my point of view. So what is important in order to see the meaning of the spirit in the Zanzibarian reality I think it is important for us to see how they make sense within Zanzibarian cosmology. Then of course it is to me to step aside, given that it's possible to achieve an understanding of how Zanzibarian look upon this, how do I then see their role in the wider Zanzibarian social system or in their social organization. Why and how is it becoming meaningful to Zanzibarian relationship, of social interactions? One of the reasons why I have decided to talk about them as beings and as real, it is because within anthropology there is a huge body of literature analyzing the spirit possession phenomenon, using terms such as "possession" of which there are often you do not find an equivalent term in the vernacular language. All will use terms such as "trance" without really knowing what we mean by "trance"... it does not tell as much. We have a lot of discussion talking about the function of spirits, explaining the spirits as if it is something collective and it allows the individual to express something that he would not necessarily be allowed to. The analyse stops there, without trying to go further in trying to see how and why they are meaningful.

Public: Do you have any information of the place where the spirits are dwelling when they are not in the body of a human? Perhaps this question will help to answer the issue of the difference between performance and ritual. body.

Public: Where are they then?

Kjersti Larsen: As I said they have the spirit world of their own.

Public: The people are talking about it?

Kjersti Larsen: Of course it is a full cosmology.

Public: Is it localized geographically?

Kjersti Larsen: No, they do not have a place because this is entering into a wider Muslim cosmology where you have demons, and they are operated by god, they are not angels, they are spirits.

\section{NOTES}

1. I have conducted social anthropological fieldwork in Zanzibar since 1984 until present.

2. Zanzibaris categorize beings as follows: angels (malaika), spirits (majini or masheitani), human beings (binadamu) and animals (wanyama), while Islamic theology distinguishes between angels, jini, sheitani and human beings. People use the terms masheitani and majini interchangeably when referring to the spirits. My preference for the term masheitani is grounded in the fact that in the context of everyday-life people tend to favour this term. The term pepo, meaning wind or air, is also sometimes used when referring to the spirits. Yet most of the time even the specialists will use the terms interchangeably and to refer to the same phenomenon - or rather the same kind of beings. 
3. The cosmology of Zanzibari women and men is conceptually centred on earth, heaven and hell. While heaven represents God or Allah and everything good, hell represents the Devil - that is, Ibilis - and everything bad.

4. In other words, the importance of spirits has to do with individual concerns within a Muslim universe rather than with scripturalist Islamic discourses. Still, as spirits form part of a Zanzibari reality, the position of spirits within a broader Islamic cosmology is an issue that people continuously discuss. There are ongoing discussions about the abilities of spirits, the nature of relationships between God, spirits and humans, and how humans ought to relate to spirits.

5. The various rituals are not categorized as masculine or feminine. Yet although men in Zanzibar Town fully participate in the phenomenon of masheitani as such, they do not, as already discussed, take part in ngoma ya kibuki to the same extent. The audience is composed mainly of women and some homosexual men .Men would usually claim that the masheitani ya kibuki are not true spirits, in the sense of being spirits created by God. They explain this by saying that masheitani ya kibuki originate from worms (funza) in the skeletons of dead people of the Sakalava kingdom of Madagascar who then become transformed into spirits. 1 This is a narrative that women, including those involved in the rituals, confirm. Thus, there is no disagreement about the origin of the masheitani ya kibuki being different from that of the other spirits. The particular origin narrative of masheitani ya kibuki is, generally speaking, not understood as a contradiction - that is, between originating from ske.letons and being created by God.

6. The woman who is arranging this ritual on behalf of her spirit, that is, mwele, spends most of the time in a room arranged for her in the house where she has receives the necessary remedies and knowledge about the particularities of 'her spirit', where also her family members and friends can come to visit her.

7. The different tribes of spirits are claimed to have their own language, although they mostly speak in Swahili.

8. In the kibuki language they sing: Miuzuna Faize o,o, Faize. Miuzuna Faize o,o, Faize. Muonzunga sangwa faindani: 'Mizuna Faize o, o. we are coming, receive us as we are bringing mwele.'

9. In the kibuki language they say: "Quesi tunku, laifandi ya nao mwenye mishulhu miwaluwalu, mitungalika". The words have been translated to me from kibuki into Swahili.

10. This song is in the kibuki language: 'Barissa mgaragara oyanile Akoriya limalewa oyanilembuki msakalava oyanileooo sasa mbela. Walolo, walolo, walolo ooo walolo, walolo, walolo ooowendao maji mawendekibani kibaratimwala kabari'.

11. Apart from the leader Bi Amani, there are two other women in this ritual group who also have (kuwa na) the king among masheitani ya kibuki, and, as mentioned above, the spirit can only inhabit one of them at a time. Despite the fact that several women have the king among masheitani ya kibuki, only Bi Amani is the ritual leader. Thus, having the spirit of the highest rank does not necessarily turn a person into a ritual leader (fundi). Still, no one becomes a ritual leader unless she is embodying the king among masheitani ya kibuki.

12. Many of those who prefer to participate as part of the distanced audience do not come forward to greet the spirits. However, sometimes the spirit will go and fetch them in order to force them to perform the prescribed greetings.

13. Female spirits openly show affection towards people and other spirits whom they favour. They sit on people's laps and give away vikuba, perfume and brandy. They kiss and rub someone's cheek and smooth someone's hair. Female spirits also express protectiveness by warning people in the audience about the strictness of some of the male spirits in order to prevent problems and disputes between people in the audience and these male spirits - or rather, to protect humans from the capricious character of certain male spirits. Male spirits are responsible for protecting the participants from groups of children and youths who, they claim, have come to destroy the celebration. 
14. Children between the age of six and twelve years participate by playing the rattles and dancing with the spirits. These are often the children of women belonging to the ritual group. Children above the age of twelve may also become inhabited by spirits.

15. When the 1980s the wabuki spirits would prefer coins preferably silver coloured coins, but in the 1990s this changed and the spirit wanted notes. They expressed their discontent whenever someone in the audience offered coins only.

16. The same term barisa is according to Leslie Sharp (1993) used in Sakalava possession rituals in Ambanja to denote the containers of the mixture of burnt honey and water consumed by the spirits. The Swahili term for alcohol is usually ulewi.

17. From time to time I would be told, especially by men, that ngoma ya kibuki are rituals women perform in order to enjoy themselves and drink alcohol.

\section{ABSTRACTS}

The paper explores performance and the analysis of bodily transformations during rituals in which the participants become both disassociated from and re-associated with different dimensions of their identity. Ethnographically, the focus is on certain rituals performed in Zanzibar called ngoma ya sheitani. During the rituals, spirits embody human beings in order to materialize and act in the 'human world.' In general, the difference between humans and spirits is one of excess rather than reversal. As such, parody - not in terms of satire but rather as repetition with critical distance - seems to play an important part in bodily transformations in the context of ngoma ya sheitani. In the process of transformation, participants are engaged in the interactional creation of what can be called a 'performance reality,' which, simultaneously, is and is not a state outside time. This implies that meanings are generated in social space through performance and that performance is a fundamental dimension of any culture and important in the production of knowledge about culture. Through performance, people both enact and extend their knowledge about difference and sameness, about who they are or are not, and about various others. An important aspect of knowledge representation, the author will argue, is that ritual and performance give the participants a possibility to experience reality, in the sense that participants and audience reflect on other contexts of meaning in the performance setting, as well as in the social and cultural world from which ritual emerges. As such, performances form part of the language of aesthetics.

Kjersti Larsen analyse la transformation du corps dans des rituels où les participants acquièrent différentes identités. A Zanzibar, pendant les cérémonies du ngoma ya sheitani, les esprits habitent les participants dans le but de se matérialiser et d'agir parmi les hommes. La parodie un jeu de répétition et de distance critique - y joue un rôle décisif. Les protagonistes sont engagés dans une création interactive. Ils explorent leurs savoirs sur le différent et le même, sur ce qu'ils sont et ce qu'ils ne sont pas. Donnant la possibilité d'endosser successivement plusieurs identités et de se projeter dans des contextes différents, la performance se révèle être comme une discipline mentale visant la production de connaissances nouvelles. 


\section{AUTHOR}

\section{KJERSTI LARSEN}

Kjersti Larsen est Professeur associé d'Anthropologie Sociale au département d'ethnographie du Musée d'histoire culturelle de l'Université d'Oslo. A partir de 1984, elle mène des recherches de terrain à Zanzibar et, à partir de 1997, dans le nord du Soudan. Ses centres d'intérêts sont l'identité, le genre et les notions de différence ; le rituel et la performance ; la religion, la modernité et le multiculturalisme, l'émigration et la mobilité. 